\title{
Triage of hrHPV-positive women: comparison of two commercial methylation-specific PCR assays
}

\author{
Carolin Dippmann 1,2, Martina Schmitz², Kristina Wunsch², Stefanie Schütze ${ }^{1}$, Katrin Beer ${ }^{1}$, Christiane Greinke ,
} Hans Ikenberg ${ }^{3}$, Heike Hoyer ${ }^{4}$, Ingo B. Runnebaum ${ }^{1}$, Alfred Hansel ${ }^{2}$ and Matthias Dürst ${ }^{1 *}$ (D)

\begin{abstract}
Aim: High-risk human papillomavirus (hrHPV)-based screening is becoming increasingly important, either by supplementing or replacing the traditional cytology-based cervical Pap smear. However, hrHPV screening lacks specificity, because it cannot differentiate between transient virus infection and clinically relevant hrHPV-induced disease. Therefore, reliable triage methods are needed for the identification of HPV-positive women with cervical intraepithelial neoplasia (CIN) in need of treatment. Promising tools discussed for the triage of these patients are molecular diagnostic tests based on epigenetic markers. Here, we compare the performance of two commercially available DNA methylation-based diagnostic assays_-GynTect ${ }^{\circledR}$ and the QIAsure Methylation Test—in physician-taken cervical scrapes from 195 subjects.
\end{abstract}

Findings: Both GynTect ${ }^{\circledR}$ and the QIAsure Methylation Test detected all cervical carcinoma and carcinoma in situ (CIS). The differences observed in the detection rates between both assays for the different grades of cervical lesions (QIAsure Methylation Test: CIN1 26.7\%, CIN2 27.8\% and CIN3 74.3\%; GynTect ${ }^{\circledR}$ : CIN1 13.3\%, CIN2 33.3\% and CIN3 $60 \%$ ) were not significant. Concerning the false-positive rates, significant differences were evident. For the healthy (NILM) hrHPV-positive group, the false-positive rates were 5.7\% for GynTect ${ }^{\circledR}$ and $26.4 \%$ for QIAsure Methylation Test $(p=0.003)$ and for the NILM hrHPV-negative group $2.2 \%$ vs. $23.9 \%(p=0.006)$, respectively. When considering hrHPVpositive samples only for comparison $(n=149)$, GynTect ${ }^{\circledR}$ delivered significantly higher specificity compared to the QIAsure Methylation Test for CIN2 + $(87.6 \%$ vs. $67.4 \%(p<0.001))$ and CIN3 + $(84.1 \%$ vs. $68.2 \%(p=0.002))$.

Overall our findings suggest that DNA methylation-based tests are suitable for the triage of hrHPV-positive women. With the goal to provide a triage test that complements the limited specificity of HPV testing in HPV-based screening, GynTect ${ }^{\circledR}$ may be preferable, due to its higher specificity for CIN2+ or CIN3+.

Keywords: Cervical cancer, CIN, DNA methylation, HPV, Triage, Epigenetic markers

\section{Background}

Cervical cancer ( $\mathrm{CxCa}$ ) is one of the most common cancers among women worldwide with both incidence and mortality rising: 570,000 newly diagnosed cases and

\footnotetext{
*Correspondence: matthias.duerst@med.uni-jena.de

${ }^{1}$ Klinik und Poliklinik für Frauenheilkunde und Fortpflanzungsmedizin, Universitätsklinikum Jena, Am Klinikum 1, 07747 Jena, Germany

Full list of author information is available at the end of the article
}

311,000 deaths in the year 2018 [1].

Through the introduction of screening programs, the incidence and mortality of cervical cancer decreased in many European countries, Australia/New Zealand and North America [1, 2]. Cytology-based diagnostics-the so-called Pap test-is the most widely used cervical cancer screening method. However, this method shows limited sensitivity for precancerous lesions [3].

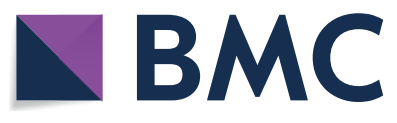

(c) The Author(s) 2020. Open Access This article is licensed under a Creative Commons Attribution 4.0 International License, which permits use, sharing, adaptation, distribution and reproduction in any medium or format, as long as you give appropriate credit to the original author(s) and the source, provide a link to the Creative Commons licence, and indicate if changes were made. The images or other third party material in this article are included in the article's Creative Commons licence, unless indicated otherwise in a credit line to the material. If material is not included in the article's Creative Commons licence and your intended use is not permitted by statutory regulation or exceeds the permitted use, you will need to obtain permission directly from the copyright holder. To view a copy of this licence, visit http://creativecommons.org/licenses/by/4.0/. The Creative Commons Public Domain Dedication waiver (http://creativeco mmons.org/publicdomain/zero/1.0/) applies to the data made available in this article, unless otherwise stated in a credit line to the data. 
For the development of cervical precancerous lesions and cancer, a persistent infection with high-risk human papillomaviruses (hrHPV) has been recognized as a necessary cause $[4,5]$. hrHPV DNA can be identified in up to 99.7\% of cervical cancers worldwide [4]. Based on these facts, testing for hrHPV infection is a highly sensitive tool for cervical cancer screening. HPV-based screening overcomes the limited sensitivity of cytology regarding precancerous lesions [3]. HPV-based screening, however, lacks specificity, and it is not possible to distinguish transient from persistent, clinically relevant hrHPV infections [6]. Furthermore, among young women HPV prevalence is high with up to $50 \%$ of the women aged below 29 years in the USA being infected with hrHPV [7]. Therefore, reliable triage methods are needed for hrHPV-positive women to identify those with cervical intraepithelial neoplasia (CIN) in need of treatment.

Different triage methods are discussed, and these include hrHPV genotyping, p16/Ki-67 cytological dual staining, altered expression profile of viral genes, and viral or host cell DNA methylation analysis $[8,9]$. A promising tool, which gained most attention recently for the triage of hrHPV-positive women, is the application of host cell DNA methylation marker analysis [10]. The change of DNA methylation patterns-especially hypermethylation of promoter and $5^{\prime}$ regions of tumour suppressor genes-is an early event in carcinogenesis [11, $12]$ and may thus be very useful in cancer diagnostics [13].

In the field of colorectal cancer diagnosis, Cologuard ${ }^{\circledR}$ and Epi proColon ${ }^{\circledR}$ have played a pioneering role. Both assays are based on the detection of the hypermethylation either of the genes NDRG4 and BMP3 (Cologuard ${ }^{\circledR}$ ) or SEPT9 (Epi proColon ${ }^{\circledR}$ ) $[14,15]$. A methylation analysis of the biomarker SEPT9 is also used for the detection of hepatocellular carcinoma (HCCBloodTest) [16]. For cervical cancer screening triage, the two best known commercially available DNA methylation-based diagnostic assays are: (1) GynTect ${ }^{\circledR}$, based on methylated DNA regions in the promoter $/ 5^{\prime}$ regions of the genes $A S T N 1$, DLX1, ITGA4, RXFP3, SOX17, and ZNF671 and (2) the QIAsure Methylation Test with the associated methylation markers FAM19A4 and miR124-2.

In the present work, we investigated the performance of GynTect ${ }^{\circledR}$ in comparison with the QIAsure Methylation Test as triage assays in 195 cervical scrapes.

\section{Results}

In this study, the DNA methylation-based diagnostic assays GynTect ${ }^{\circledR}$ and the QIAsure Methylation Test were assessed for their performance as triage tests for hrHPV-positive women. For this comparison, 195 cervical scrapes were analysed by both assays. Of these, 46 samples were cytologically normal (NILM) and hrHPVnegative, and all other samples were hrHPV-positive. The mean age of the patients was 40.5 years (range 19-84).

Overall, the QIAsure Methylation Test had a somewhat higher detection rate among CIN samples than GynTect $^{\circledR}$, but these differences were not significant. In contrast, significant differences in the detection rates were observed for NILM samples, irrespective of the hrHPV status (Table 1).

In Table 2, the diagnostic performance of the GynTect ${ }^{\circledR}$ assay and QIAsure Methylation Test with respect to CIN2+ and CIN3+ in terms of sensitivity and specificity is summarized. Importantly, these measures were estimated for the hrHPV-positive subgroup only, since the tests were designed as triage option for this patient group. Significant differences are only evident for specificity in case of CIN2+ and CIN3+ (Table 2).

Moreover, we calculated the predictive values for both assays for CIN3+ by applying the Bayes theorem for a meaningful disease prevalence. We assume a CIN3+ prevalence of $30 \%$ for a triage setting of hrHPV-positives and values for sensitivity and specificity as shown in Table 2. With this constellation, the positive predictive values would be $64.3 \%$ for GynTect ${ }^{\circledR}$ and $51.4 \%$ for the QIAsure Methylation Test and the negative predictive values would be $85.5 \%$ and $88.1 \%$, respectively.

\section{Discussion}

The limited sensitivity of cytology-based screening [3] has led to the introduction of HPV-based screening in several countries (e.g. Great Britain, Netherlands, San Marino, Turkey, Germany) $[17,18]$. The specificity of HPV testing for cervical cancer, however, is very low. Recently, Leeman et al. reported a high sensitivity of hrHPV testing for CIN3+ of $90.3 \%$, but a specificity of only $31.8 \%$ [19]. These findings are consistent with many previous studies [20-22].

Hypermethylation in certain promoter regions is an early event in carcinogenesis. Thus, methylation markers are getting increasing awareness as promising triage tools for hrHPV-positive women [9, 11, 19, 23, 24], and as a consequence diagnostic tests are emerging based on this marker class [13].

With this study, we provide a comparison of the performance of two commercially available DNA methylation-based diagnostic assays-GynTect ${ }^{\circledR}$ and QIAsure Methylation Test-regarding sensitivity and specificity in a sample comprising 195 cervical scrapes. The purpose was to evaluate the assays as potential triage tools for HPV-based cervical cancer screening.

Our study confirmed the extremely high sensitivity of the DNA methylation tests for the detection of cancer cases. Both assays recognized all cancer and CIS cases. 
Table 1 Detection rates of both assays according to histological/cytological and hrHPV findings $(n=195)$

\begin{tabular}{|c|c|c|c|c|c|}
\hline & \multicolumn{2}{|l|}{ GynTect $^{\circledR}$} & \multicolumn{2}{|c|}{ QIAsure Methylation Test } & \multirow{2}{*}{$\begin{array}{l}P \text { value } \\
\text { for comparison } \\
\text { of detection rate }\end{array}$} \\
\hline & Test positive & $\begin{array}{l}\text { Detection rate [\%] } \\
(95 \% \mathrm{Cl})\end{array}$ & Test positive & $\begin{array}{l}\text { Detection rate [\%] } \\
(95 \% \mathrm{Cl})\end{array}$ & \\
\hline \multicolumn{6}{|l|}{ hrHPV + } \\
\hline $\begin{array}{l}\mathrm{CxCa} \\
(n=2)\end{array}$ & 2 & $2 / 2^{*}$ & 2 & $2 / 2^{*}$ & - \\
\hline $\begin{array}{l}\mathrm{CIS} \\
(n=5)\end{array}$ & 5 & $5 / 5^{*}$ & 5 & $5 / 5^{*}$ & - \\
\hline $\begin{array}{l}\mathrm{CIN} 3 \\
(n=35)\end{array}$ & 21 & $\begin{array}{l}60.0 \\
(42.1-76.1)\end{array}$ & 26 & $\begin{array}{l}74.3 \\
(56.7-87.5)\end{array}$ & 0.125 \\
\hline $\begin{array}{l}\mathrm{CIN} 2 \\
(n=18)\end{array}$ & 6 & $\begin{array}{l}33.3 \\
(13.3-59.0)\end{array}$ & 5 & $\begin{array}{l}27.8 \\
(9.7-53.5)\end{array}$ & 1.000 \\
\hline $\begin{array}{l}\mathrm{CIN} 1 \\
(n=15)\end{array}$ & 2 & $\begin{array}{l}13.3 \\
(1.7-40.5)\end{array}$ & 4 & $\begin{array}{l}26.7 \\
(7.8-55.1)\end{array}$ & 0.500 \\
\hline $\begin{array}{l}\text { no CIN } \\
(n=21)\end{array}$ & 6 & $\begin{array}{l}28.6 \\
(11.3-52.2)\end{array}$ & 11 & $\begin{array}{l}52.4 \\
(29.8-74.3)\end{array}$ & 0.125 \\
\hline $\begin{array}{l}\text { NILM } \\
(n=53)\end{array}$ & 3 & $\begin{array}{l}5.7 \\
(1.2-15.7)\end{array}$ & 14 & $\begin{array}{l}26.4 \\
(15.3-40.3)\end{array}$ & 0.003 \\
\hline \multicolumn{6}{|l|}{ hrHPV - } \\
\hline $\begin{array}{l}\text { NILM } \\
(n=46)\end{array}$ & 1 & $\begin{array}{l}2.2 \\
(0.1-11.5)\end{array}$ & 11 & $\begin{array}{l}23.9 \\
(12.6-38.8)\end{array}$ & 0.006 \\
\hline
\end{tabular}

*Due to the low number of cases we present absolute frequencies for description and omit percentages and statistical comparisons

Table 2 Clinical performance of both assays regarding the detection of CIN2+ and CIN3+ in the hrHPV-positive subgroup $(n=149)$

\begin{tabular}{|c|c|c|c|c|}
\hline & True positive & $\begin{array}{l}\text { Sensitivity [\%] } \\
(95 \% \mathrm{Cl})\end{array}$ & True negative & $\begin{array}{l}\text { Specificity [\%] } \\
(95 \% \mathrm{Cl})\end{array}$ \\
\hline \multicolumn{5}{|l|}{$\mathrm{CIN} 2+$} \\
\hline GynTect ${ }^{\circledR}$ & $34 / 60$ & $\begin{array}{l}56.7 \\
(43.2-69.4)\end{array}$ & $78 / 89$ & $\begin{array}{l}87.6 \\
(79.0-93.7)\end{array}$ \\
\hline QIAsure Methylation Test & $38 / 60$ & $\begin{array}{l}63.3 \\
(49.9-75.4)\end{array}$ & $60 / 89$ & $\begin{array}{l}67.4 \\
(56.7-77.0)\end{array}$ \\
\hline$P$ value & & 0.424 & & $<0.001$ \\
\hline \multicolumn{5}{|l|}{$\mathrm{CIN} 3+$} \\
\hline GynTect ${ }^{\circledR}$ & $28 / 42$ & $\begin{array}{l}66.7 \\
(50.5-80.4)\end{array}$ & $90 / 107$ & $\begin{array}{l}84.1 \\
(75.8-90.5)\end{array}$ \\
\hline QIAsure Methylation Test & $33 / 42$ & $\begin{array}{l}78.6 \\
(63.2-89.7)\end{array}$ & 73/107 & $\begin{array}{l}68.2 \\
(58.5-76.9)\end{array}$ \\
\hline$P$ value & & 0.125 & & 0.002 \\
\hline
\end{tabular}

Similar results were also shown before for GynTect ${ }^{\circledR}$ with 123/123 CxCa detected and the QIAsure Methylation Test with 510/519 CxCa detected [9, 25]. Moreover, for GynTect $^{\circledR}$ the detection rates for different stages of CIN ranged from $13.3 \%$ for CIN1 over $33.3 \%$ for CIN2 to $60 \%$ for CIN3. In a previous study, Schmitz et al. achieved detection rates within the same range (CIN1: 20\%; CIN2: 44.4\%; CIN3: 61.2\%) [26]. For the QIAsure Methylation Test, the detection rates were $26.7 \%$ for CIN1, 27.8\% for CIN2, and $74.3 \%$ for CIN3 (Table 1). With exception of the CIN2 cases, these positivity rates also correlate with previous studies (CIN1: 27.7\%; CIN2: 44.3\%; CIN3: 75.8\%) [19].

Surgical removal of a precancerous lesion is the recommended treatment for histologically confirmed CIN2-3 [27]. Based on this recommendation, a more detailed assessment of the detection rates of CIN2 and CIN3 by the two assays is warranted. GynTect ${ }^{\circledR}$ detected around $33-60 \%$ of these lesions, whereas QIAsure Methylation Test showed detection rates of $28-74 \%$. In this context, it is important to consider that not all CIN3 progress to cervical cancer [28] and that the majority of CIN1 and 
CIN2 regress without treatment. Wang et al. showed that among women with CIN2 $(n=25) 56 \%$ regressed to normal, $24 \%$ to CIN1, $4 \%$ remained as CIN2, and $16 \%$ progressed to CIN3+ within six years [29]. Loopik et al. reported similar data-regression of CIN2 in $71.1 \%$ of cases and a progression from CIN2 to CIN3 in 16.6\% of cases among women younger than $25(n=150)$ [30]. In the light of these studies, it is clear that an ideal triage test should allow to discriminate between high-grade lesions with a low risk for progression and clinically relevant lesions, which obviously are not distinguishable by histopathology. The two assays investigated in the present study may provide such a possibility. However, this needs to be confirmed in prospective observational studies which are currently ongoing.

Regarding the detection rates within the "no CIN" group (GynTect ${ }^{\circledR}: 28.6 \%$, QIAsure Methylation Test: $52.4 \%$ ), it is important to note that this population comprises exclusively women who were referred to colposcopy for diagnostic workup. These patients showed abnormal cytology and hrHPV positivity. However, the biopsies taken revealed no CIN. In a recently published study, the positivity rate of the QIAsure Methylation Test was 23.2\% for hrHPV-positive "no CIN" cases and 25.4\% for CIN1 [31]. We have no explanation for the high QIAsure positivity rate for "no CIN" samples in our study population. Nevertheless, the methylation rate among "no CIN" samples is markedly higher than for CIN1 in the respective assays, suggesting that in some cases biopsy may have missed subclinical high-grade lesions.

Of particular interest is the performance of the assays for hrHPV-negative NILM cases. In this group, 2.2\% were positive for GynTect $^{\circledR}$, but $23.9 \%$ for the QIAsure Methylation Test $(p=0.006)$. Considering the fact that a persistent infection with hrHPV types is a prerequisite for cervical carcinogenesis, the methylation rate among hrHPV-negative NILM cases reflects unspecific background methylation. We could not find any data in the literature reporting results of the QIAsure Methylation Test for hrHPV-negative NILM cases only. Also for hrHPV-positive NILM cases, the QIAsure Methylation Test has much higher positivity rates compared to GynTect $^{\circledR}(26.4 \%$ vs $5.7 \%$, respectively, $p=0.003)$. As for the hrHPV-negative NILM cases, we could not find published data on the performance of the QIAsure Methylation Test for hrHPV-positive NILM cases only. Thus, in a triage setting, it is very likely that the QIAsure Methylation Test would lead to higher colposcopy referrals in comparison with the GynTect ${ }^{\circledR}$ assay.

Besides the methylation markers ASTN1, DLX1, ITGA4, RXFP3, SOX17, ZNF671 (GynTect ${ }^{\circledR}$ ) and FAM19A4, miR124-2 (QIAsure Methylation Test), other markers are discussed [23, 24, 32]. Bierkens et al. showed an increased methylation level of the markers CADM1 and $M A L$ with increasing severity of the lesion (5.3-6.2fold in CIN2/3 and 143.5-454.9-fold in cervical cancer cases) [23]. In another study, $C A D M 1$ and $M A L$ displayed a CIN3+ sensitivity of $70 \%$ and a CIN3+ specificity of $78 \%$ in the triage of hrHPV-positive women [32]. A four-gene methylation marker panel consisting of the markers JAM3, EPB41L3, TERT and C13ORF18 revealed a CIN3+ sensitivity of $84 \%$ and a specificity of $69 \%$ for hrHPV-positive cervical scrapes [24]. Compared to the results achieved in the current study, the sensitivity of the above-mentioned methylation markers is in a similar range. Regarding specificity, however, GynTect ${ }^{\circledR}$ shows the best results for CIN3+.

\section{Conclusion}

An ideal screening strategy for cervical cancer is characterized by maximum sensitivity to detect all cases with clinically relevant disease and maximum specificity to reduce false positive results and ultimately also overtreatment. Methylation-based triage tests for hrHPV-positive women are highly promising. In particular, the GynTect ${ }^{\circledR}$ assay convinces with high sensitivity and unmatched specificity.

\section{Methods}

\section{Patient samples}

Cervical scrapes were collected from patients attending the dysplasia unit at the Department of Gynaecology and Reproductive Medicine at the Jena University Hospital (Germany). Further samples were available from a previous study conducted with CytoMol, Frankfurt, Germany. All of the above samples comprise cervical scrapes in PreservCyt ${ }^{\circledR}$ liquid-based cytology (LBC) media (Hologic, Wiesbaden, Germany).

For each sample, information regarding cytology or, in cases in which a biopsy was taken, the histopathological diagnosis was available. The samples included in this study had the following cytology findings or histopathological diagnosis: normal cytology (NILM) and hrHPVnegative $(n=46)$; NILM and hrHPV-positive but no biopsy taken $(n=53)$; colposcopically suspect but normal histopathology on biopsy (=no CIN) $(n=21)$; CIN1 $(n=15) ; \operatorname{CIN} 2(n=18) ; \operatorname{CIN} 3(n=35) ; \mathrm{CIS}(n=5)$ and CxCa $(n=2)$. All cases of no CIN, CIN1, CIN2, CIN3, $\mathrm{CIS}$, and cancers were hrHPV-positive.

\section{DNA isolation and HPV testing}

For the QIAsure Methylation Test (Qiagen, Hilden, Germany), DNA was isolated from $5 \mathrm{ml}$ of the LBC sample by use of the NucleoSpin ${ }^{\circledR}$ Tissue Kit (Macherey Nagel, Düren, Germany) according to the manufacturer's instructions. Concentration of genomic DNA was 
measured using a NanoDrop 2000 UV-Vis spectrophotometer (VWR, Erlangen, Germany). HPV status of the samples was determined using the GP5+/6+ PCR-EIA assay [33] or the cobas ${ }^{\circledR}$ HPV test (Roche, Mannheim, Germany).

\section{DNA methylation marker analysis}

GynTect $^{\circledR}$ The GynTect $^{\circledR}$ assay (oncgnostics GmbH, Jena, Germany), which analyses the six DNA methylation markers ASTN1, DLX1, ITGA4, RXFP3, SOX17, ZNF671 and two controls (ACHE, IDS), was performed for all samples as described in the instructions for use (oncgnostics GmbH, Jena, Germany).

Briefly, LBC samples were vortexed and $1 \mathrm{ml}$ was immediately transferred into a $2-\mathrm{ml}$ reaction tube. Cells were pelleted by centrifugation, and $900 \mu$ l supernatant was discarded. $40 \mu \mathrm{l}$ of the resuspended cells was used for bisulfite treatment using the EpiTect ${ }^{\circledR}$ Fast Bisulfite Kit (Qiagen, Hilden, Germany) following the supplier's manual without previous DNA isolation. After elution (in $20 \mu \mathrm{l}$ ), the sample volume was increased by adding $70 \mu \mathrm{l}$ water.

The GynTect ${ }^{\circledR}$ methylation-specific real-time PCR was performed using custom-made real-time PCR Master Mix (MM), containing a Hotstart DNA polymerase. $10 \mu \mathrm{l}$ of this MM was added to each vial in an eight-tube strip, each containing a different pair of the pre-dried primers for the respective markers. $10 \mu \mathrm{l}$ of the bisulfite-converted DNA, serving as a template for each marker, was added to each tube. The PCRs were performed using the ABI7500 PCR system (Life Technologies, Thermo Fisher Scientific, USA). A detailed description of the GynTect ${ }^{\circledR}$ methylation-specific real-time PCR has been published previously [21].

For each methylation marker, the $\mathrm{Ct}$ value was determined and a delta $\mathrm{Ct}$ was calculated using the $\mathrm{Ct}$ value of the methylation control marker IDS as reference (prerequisite: $\mathrm{Ct}$ value IDS $\leq 32$ ). To score a methylation marker as positive, the delta $\mathrm{Ct}\left(\mathrm{Ct}_{\text {Marker }}-\mathrm{Ct}_{\text {IDS }}\right)$ has to be $\leq 8$ for ASTN1, $\leq 9$ for DLX1, ITGA4, RXFP3, and SOX17, and $\leq 10$ for ZNF671. The whole GynTect ${ }^{\circledR}$ assay was considered positive if the amount of all methylation marker scores was 6 or higher (single-marker scores $D L X 1$ : 1; ASTN1, ITGA4, RXFP3, SOX17: each 2; and ZNF671: 6).

QIAsure Methylation Test The QIAsure Methylation Test (Qiagen, Hilden, Germany) analyses in a multiplex methylation-specific real-time PCR the methylation of the promoter regions of FAM19A4 and miR124-2 and a reference gene $(A C T B)$. The test was performed for all samples as described in the instructions for use (Qiagen, Hilden, Germany).
Briefly, genomic DNA was isolated and its concentration measured as described in "DNA isolation and HPV testing" above. In the bisulfite reaction up to $300 \mathrm{ng} / 45 \mu \mathrm{l}$, isolated genomic DNA was converted using the EZ DNA Methylation Kit following the instructions of the supplier (Zymo Research Europe, Freiburg, Germany). DNA was eluted in $10 \mu \mathrm{l}$.

To perform the QIAsure Methylation Test, $17.5 \mu \mathrm{l}$ custom-made real-time PCR MM and 2,5 $\mu$ template were needed. The multiplex PCR was run on a Rotor-Gene ${ }^{\circledR} \mathrm{Q}$ MDx 5plex system (Qiagen, Hilden, Germany).

The samples were scored hypermethylation-positive if the $\mathrm{Ct}$ value of $A C T B$ was $\leq 26.4$, and at least one of the methylation marker genes had a $\Delta \Delta$ Ct below the cut-off [19].

\section{Statistical evaluation}

For both assays, detection rate was calculated according to the histologically confirmed cervical disease status (cytology for the NILM group). Sensitivity and specificity were estimated for the diagnosis of CIN2 or higher $(\mathrm{CIN} 2+)$ and CIN3 or higher (CIN3+) with exact twosided $95 \%$ confidence intervals $(\mathrm{CI})$ assuming a binomial distribution. Performance of both methylation-based diagnostic assays was statistically compared by the McNemar's test. The two-sided level of significance was set to 0.05 . Predictive values were calculated for a reasonable prevalence by applying the Bayes theorem. Statistical analysis was performed using GraphPad Prism (Version 5.00 for Windows, GraphPad Software, San Diego, California, USA) and SAS (Version 9.4).

\section{Abbreviations}

ACHE: Acetylcholinesterase; ACTB: $\beta$-Actin; ASTN1: Astrotactin 1; BMP3: Bone morphogenetic protein 3; C13ORF18: Rubicon-like autophagy enhancer; CADM1: Cell adhesion molecule 1; Cl: Confidence interval; CIN: Cervical intraepithelial neoplasia; CIS: Carcinoma in situ; Ct: Cycle threshold; CXCa: Cervical cancer; DLX1: Distal-less homeobox 1; DNA: Deoxyribonucleic acid; EPB41L3: Erythrocyte membrane protein band 4.1 like 3; FAM19A4: Family with sequence similarity 19 member A4; HPV: Human papillomavirus; hrHPV: Highrisk HPV; IDS: Iduronate 2-sulfatase; ITGA4: Integrin subunit alpha 4; JAM3: Junction adhesion molecule 3; Ki-67: Marker of proliferation; LBC: Liquidbased cytology; MAL: T-lymphocyte maturation-associated protein; miR124-2: MicroRNA 124; MM: Master mix; NDRG4: N-Myc downstream-regulated gene 4; NILM: Negative for intraepithelial lesion and malignancy, meaning normal cytology; p16: Cyclin-dependent kinase inhibitor 2A; PCR: Polymerase chain reaction; RXFP3: Relaxin/insulin-like family peptide receptor 3; SEPT9: Septin 9; SOX17: Sex determining region Y-box 17; TERT: Telomerase reverse transcriptase; ZNF671: Zinc finger protein 671.

\section{Acknowledgements}

Not applicable.

\section{Authors' contributions}

$M D, C D, M S$, and $A H$ were responsible for study conception, design, and supervision. HI, SS, and IBR were responsible for clinical findings and providing the samples. CD performed the experiments and analysed the data. KB and CG were responsible for HPV DNA testing with GP5+/6+ PCR-EIA assay. KW was involved in performance of the GynTect ${ }^{\circledR}$ assay. $\mathrm{HH}$ performed the 
statistical analyses. CD, AH, MS, and MD wrote the manuscript. All authors have read and approved the final manuscript.

\section{Funding}

The authors received no specific funding for this work.

\section{Availability of data and materials}

The raw data generated in this study are available from the corresponding author on reasonable request.

\section{Ethics approval and consent to participate}

This work was approved by the ethics committee of the Friedrich Schiller University Jena (Reference Numbers 2174-12/07 and 3471-06/12). Samples from CytoMol comprise anonymized surplus samples from routine cervical cancer screening that otherwise would have been discarded. The Department of Gynaecology and Reproductive Medicine at the Jena University Hospital contributed to the study with pseudonymized surplus samples. The study was performed following the guideline of the Declaration of Helsinki.

\section{Consent for publication}

Not applicable.

\section{Competing interests}

MS, AH, KW, and MD are minority shareholders and/or employees of oncgnostics $\mathrm{GmbH}$, a company that aims to commercialize DNA methylation markers. $\mathrm{CD}$ receives a PhD fellowship financed by oncgnostics $\mathrm{GmbH}$ and ESF.

\section{Author details}

${ }^{1}$ Klinik und Poliklinik für Frauenheilkunde und Fortpflanzungsmedizin, Universitätsklinikum Jena, Am Klinikum 1, 07747 Jena, Germany. ${ }^{2}$ Oncgnostics GmbH, Winzerlaer Straße 2, 07745 Jena, Germany. ${ }^{3}$ MVZ CytoMol, Berner Straße 76, 60437 Frankfurt am Main, Germany. ${ }^{4}$ Institut Für Medizinische Statistik, Informatik und Datenwissenschaften, Universitätsklinikum Jena, Bachstraße 18, 07743 Jena, Germany.

\section{Received: 4 September 2020 Accepted: 28 October 2020}

Published online: 11 November 2020

\section{References}

1. Bray F, Ferlay J, Soerjomataram I, Siegel RL, Torre LA, Jemal A. Global cancer statistics 2018: GLOBOCAN estimates of incidence and mortality worldwide for 36 cancers in 185 countries. CA Cancer J Clin. 2018;68(6):394-424

2. Anttila A, Ronco G, Working Group on the Research, Monitoring of Cervical Cancer Screening Programmes in the European Union, within the European Network for Information on Cancer. Description of the national situation of cervical cancer screening in the member states of the European Union. Eur J Cancer. 2009;45(15):2685-708.

3. Mayrand MH, Duarte-Franco E, Rodrigues I, Walter SD, Hanley J, Ferenczy A, et al. Human papillomavirus DNA versus Papanicolaou screening tests for cervical cancer. N Engl J Med. 2007;357(16):1579-88.

4. Walboomers JM, Jacobs MV, Manos MM, Bosch FX, Kummer JA, Shah $\mathrm{KV}$, et al. Human papillomavirus is a necessary cause of invasive cervical cancer worldwide. J Pathol. 1999;189(1):12-9.

5. Steenbergen RD, de Wilde J, Wilting SM, Brink AA, Snijders PJ, Meijer CJ. HPV-mediated transformation of the anogenital tract. J Clin Virol. 2005;32(Suppl 1):S25-33.

6. De Strooper LMA, Verhoef VMJ, Berkhof J, Hesselink AT, de Bruin HME, van Kemenade FJ, et al. Validation of the FAM19A4/mir124-2 DNA methylation test for both lavage- and brush-based self-samples to detect cervical (pre)cancer in HPV-positive women. Gynecol Oncol. 2016;141(2):341-7.

7. Markowitz LE, Hariri S, Lin C, Dunne EF, Steinau M, McQuillan G, et al. Reduction in human papillomavirus (HPV) prevalence among young women following HPV vaccine introduction in the United States, National Health and Nutrition Examination Surveys, 2003-2010. J Infect Dis. 2013;208(3):385-93.

8. Wentzensen N, Schiffman M, Palmer T, Arbyn M. Triage of HPV positive women in cervical cancer screening. J Clin Virol. 2016;76(Suppl 1):S49-55.
9. Hansel A, Steinbach D, Greinke C, Schmitz M, Eiselt J, Scheungraber $\mathrm{C}$, et al. A promising DNA methylation signature for the triage of high-risk human papillomavirus DNA-positive women. PLoS ONE. 2014;9(3):e91905

10. Steenbergen RD, Snijders PJ, Heideman DA, Meijer CJ. Clinical implications of (epi)genetic changes in HPV-induced cervical precancerous lesions. Nat Rev Cancer. 2014;14(6):395-405.

11. Baylin SB, Ohm JE. Epigenetic gene silencing in cancer - a mechanism for early oncogenic pathway addiction? Nat Rev Cancer. 2006;6(2):107-16.

12. Wentzensen N, Sherman ME, Schiffman M, Wang SS. Utility of methylation markers in cervical cancer early detection: appraisal of the state-ofthe-science. Gynecol Oncol. 2009;112(2):293-9.

13. Locke WJ, Guanzon D, Ma C, Liew YJ, Duesing KR, Fung KYC, et al. DNA methylation cancer biomarkers: translation to the clinic. Front Genet. 2019;10(1150).

14. Imperiale TF, Ransohoff DF, Itzkowitz SH, Levin TR, Lavin P, Lidgard GP, et al. Multitarget stool DNA testing for colorectal-cancer screening. N Engl J Med. 2014;370(14):1287-97.

15. deVos T, Tetzner R, Model F, Weiss G, Schuster M, Distler J, et al. Circulating methylated SEPT9 DNA in plasma is a biomarker for colorectal cancer. Clin Chem. 2009;55(7):1337-46.

16. Oussalah A, Rischer S, Bensenane M, Conroy G, Filhine-Tresarrieu P, Debard R, et al. Plasma mSEPT9: a novel circulating cell-free DNA-based epigenetic biomarker to diagnose hepatocellular carcinoma. EBioMedicine. 2018;30:138-47.

17. Chrysostomou AC, Stylianou DC, Constantinidou A, Kostrikis LG. Cervical Cancer Screening Programs in Europe: The transition towards HPV vaccination and population-based HPV testing. Viruses. 2018;10(12).

18. Altobelli E, Rapacchietta L, Profeta VF, Fagnano R. HPV-vaccination and cancer cervical screening in 53 WHO European Countries: an update on prevention programs according to income level. Cancer Med. 2019;8(5):2524-34.

19. Leeman A, Del Pino M, Marimon L, Torne A, Ordi J, Ter Harmsel B, et al. Reliable identification of women with CIN3+ using hrHPV genotyping and methylation markers in a cytology-screened referral population. Int J Cancer. 2019;144(1):160-8.

20. Dijkstra MG, Heideman DA, van Kemenade FJ, Hogewoning KJ, Hesselink AT, Verkuijten MC, et al. Brush-based self-sampling in combination with GP5+/6+-PCR-based hrHPV testing: high concordance with physiciantaken cervical scrapes for HPV genotyping and detection of high-grade CIN. J Clin Virol. 2012;54(2):147-51.

21. Schmitz M, Wunsch $K$, Hoyer $H$, Scheungraber C, Runnebaum IB, Hansel $A$, et al. Performance of a methylation specific real-time PCR assay as a triage test for HPV-positive women. Clin Epigenet. 2017;9:118.

22. Arbyn M, Ronco G, Anttila A, Meijer CJ, Poljak M, Ogilvie G, et al. Evidence regarding human papillomavirus testing in secondary prevention of cervical cancer. Vaccine. 2012;30(Suppl 5):F88-99.

23. Bierkens M, Hesselink AT, Meijer CJ, Heideman DA, Wisman GB, van der Zee AG, et al. CADM1 and MAL promoter methylation levels in hrHPVpositive cervical scrapes increase proportional to degree and duration of underlying cervical disease. Int J Cancer. 2013;133(6):1293-9.

24. Eijsink JJ, Lendvai A, Deregowski V, Klip HG, Verpooten G, Dehaspe L, et al. A four-gene methylation marker panel as triage test in high-risk human papillomavirus positive patients. Int J Cancer. 2012;130(8):1861-9.

25. Vink FJ, Meijer C, Clifford GM, Poljak M, Ostrbenk A, Petry KU, et al. FAM19A4/miR124-2 methylation in invasive cervical cancer: A retrospective cross-sectional worldwide study. Int J Cancer. 2020;147(4):1215-21.

26. Schmitz M, Eichelkraut K, Schmidt D, Zeiser I, Hilal Z, Tettenborn Z, et al. Performance of a DNA methylation marker panel using liquid-based cervical scrapes to detect cervical cancer and its precancerous stages. BMC Cancer. 2018;18(1):1197.

27. Santesso N, Mustafa RA, Schunemann HJ, Arbyn M, Blumenthal PD, Cain J, et al. World Health Organization Guidelines for treatment of cervical intraepithelial neoplasia 2-3 and screen-and-treat strategies to prevent cervical cancer. Int J Gynaecol Obstet. 2016;132(3):252-8.

28. McCredie MR, Sharples KJ, Paul C, Baranyai J, Medley G, Jones RW, et al. Natural history of cervical neoplasia and risk of invasive cancer in women with cervical intraepithelial neoplasia 3: a retrospective cohort study. Lancet Oncol. 2008:9(5):425-34.

29. Wang SM, Colombara D, Shi JF, Zhao FH, Li J, Chen F, et al. Six-year regression and progression of cervical lesions of different human 
papillomavirus viral loads in varied histological diagnoses. Int J Gynecol Cancer. 2013;23(4):716-23.

30. Loopik DL, Doucette S, Bekkers RL, Bentley JR. Regression and progression predictors of CIN2 in women younger than 25 years. J Lower Genital Tract Dis. 2016;20(3):213-7.

31. Leeman A, Jenkins D, Del Pino M, Ordi J, Torne A, Doorbar J, et al. Expression of p16 and HPV E4 on biopsy samples and methylation of FAM19A4 and miR124-2 on cervical cytology samples in the classification of cervical squamous intraepithelial lesions. Cancer Med. 2020;9(7):2454-61.

32. Overmeer RM, Louwers JA, Meijer CJ, van Kemenade FJ, Hesselink AT, Daalmeijer NF, et al. Combined CADM1 and MAL promoter methylation analysis to detect (pre-)malignant cervical lesions in high-risk HPV-positive women. Int J Cancer. 2011;129(9):2218-25.
33. Jacobs MV, Snijders PJ, van den Brule AJ, Helmerhorst TJ, Meijer CJ, Walboomers JM. A general primer GP5+/GP6(+)-mediated PCR-enzyme immunoassay method for rapid detection of 14 high-risk and 6 low-risk human papillomavirus genotypes in cervical scrapings. J Clin Microbiol. 1997;35(3):791-5.

\section{Publisher's Note}

Springer Nature remains neutral with regard to jurisdictional claims in published maps and institutional affiliations.
Ready to submit your research? Choose BMC and benefit from:

- fast, convenient online submission

- thorough peer review by experienced researchers in your field

- rapid publication on acceptance

- support for research data, including large and complex data types

- gold Open Access which fosters wider collaboration and increased citations

- maximum visibility for your research: over $100 \mathrm{M}$ website views per year

At BMC, research is always in progress.

Learn more biomedcentral.com/submissions 